\title{
Pengaruh Tingkat Toleransi Beragama Terhadap Isu Radikalisme Mahasiswa Fisip Universitas Hasanuddin
}

\author{
Nur Afni Andriani S_30600119003 \\ Program Studi Ilmu Politik UIN Alauddin Makassar \\ afniandriani08@gmail.com
}

\begin{abstract}
Abstrak
Penelitian ini bertujuan untuk mengetahui pengaruh tingkat toleransi beragama terhadap isu radikalisme mahasiswa FISIP Universitas Hasanuddin. Penelitian ini melibatkan mahasiswa FISIP UNHAS sebagai responden penelitian. Rumusan masalah dalam penelitian ini adalah (1) Bagaimana tingkat toleransi beragama mahasiswa FISIP Universitas Hasanuddin?; (2) Bagaimana pengaruh tingkat toleransi beragama terhadap isu radikalisme di kalangan mahasiswa?. Jenis penelitian ini adalah penelitian survei dengan menggunakan metode penelitian kuantitatif. Populasinya adalah mahasiswa FISIP UNHAS dengan jumlah sampel 30 responden. Adapun teknik pengumpulan data diperoleh melalui angket dan wawancara. Data dianalisis menggunakan model Miles dan Huberman melalui tahap reduksi data, display data, dan penarikan kesimpulan. Pengolahan data kuesioner dilakukan dengan menggunakan bantuan program SPSS (Statistical Package for Social Science) ver.28.0. Hasil analisis data dalam penelitian ini adalah sebagai berikut; (1) mahasiswa FISIP UNHAS memiliki tingkat toleransi beragama yang tinggi yaitu sebesar 63,3\% (variabel X); (2) terdapat pengaruh yang positif antara tingkat toleransi beragama yang tinggi terhadap rendahnya isu radikalisme di kalangan mahasiswa yaitu sebanyak 36,7\% responden yang sangat tidak setuju terhadap penyebaran isu radikalisme (variabel Y). Mahasiswa hendaknya menjaga dan lebih meningkatkan kesadaran akan nilai multikultural untuk menanamkan sikap toleransi dalam menghadapi isu radikalisme. Mahasiswa hendaknya menanamkan sikap toleransi dalam kehidupan kampus baik secara akademik maupun non-akademik.
\end{abstract}

Kata kunci : Toleransi Beragama, Isu Radikalisme, Mahasiswa.

\section{A. PENDAHULUAN}

Indonesia merupakan salah satu Negara dengan multikultur terbesar di dunia. Letak geografis yang begitu kompleks, beragam dan luas menjadikan Indonesia mempunyai beragam kultur yang harus di bina dan di jaga dengan baik. Mengutip dari apa yang dikatakan oleh (Kusumohamidjojo, 2000) bahwa: "Indonesia terdiri atas 
sejumlah besar kelompok-kelompok etnis, budaya, agama dan lain-lain yang masingmasing plural (Jamak) dan sekaligus juga beraneka ragam (heterogen)". 1

Dalam suatu Negara sudah seharusnya setiap warga Negara mempunyai kesadaran atas keberagaman budaya tersebut, agar bisa terciptanya suatu tatanan masyarakat yang mempunyai kekuatan maupun kerukunan beragama serta kerukunan dalam berbangsa dan bernegara. Akan tetapi juga, tidak dapat dipungkiri bahwasannya hal tersebut cenderung membuat kemajemukan yang tercipta dikalangan masyarakat membawa potensi konflik dengan berbagai persoalan yang berbeda-beda hingga berujung pada perpecahan. Karena seperti yang kita ketahui bersama, bukan hal yang mudah untuk mempersatukan Bangsa dengan multikultural yang begitu kompleks.

Seperti yang telah diketahui sebelumnya, bahwa selain sebagai kekayaaan bangsa, multikultural yang beragam juga sangat rawan memicu konflik dan perpecahan. Oleh karena itu, (Nasikun, 2007) mengemukakan bahwa : "Kemajemukan masyarakat Indonesia paling tidak dapat dilihat dari dua cirinya yang unik, pertama secara horizontal, ia ditandai oleh kenyataan adanya kesatuan-kesatuan sosial berdasarkan perbedaan suku bangsa, agama, adat, serta perbedaan kedaerahan, dan kedua secara vertikal ditandai oleh adanya perbedaan-perbedaan vertikal antara lapisan atas dan lapisan bawah yang cukup tajam." 2

Dengan tumbuh suburnya berbagai organisasi di Indonesia seperti organisasi kemasyarakatan, profesi, dan agama bahkan sekarang sudah muncul berbagai aliran radikal yang mengatasnamakan agama membuat kita sebagai pelajar harus berhatihati dalam memasuki organisasi tertentu, baik itu organisasi kemasyarakatan, profesi maupun keagamaan. Dewasa ini, agama sudah menjadi salah satu faktor pemicu konflik. Jika kita sebagai pelajar tidak meningkatkan rasa toleransi beragama antar sesama, akan mudah bagi oknum-oknum yang tidak bertanggungjawab akan memprovokasi pemikiran kita dengan mengatasnamakan agama yang dimana agama pada dasarnya merupakan pedoman hidup bagi manusia. (Kahmad, 2009) mengemukakan bahwa: "Agama sangat rentan memunculkan persoalan-persoalan konflik (intoleransi). Ini diakibatkan posisi agama disejajarkan dengan kesukuan dan

\footnotetext{
${ }^{1}$ Kusumohamidjojo (2000: 45) Kebhinekaan Masyarakat: Suatu Problematik Filsafat Kebudayaan. Jakarta: Grasindo

${ }^{2}$ Nasikun (2007), Sistem Sosial Indonesia. Jakarta: PT. Raja Grafindo Persada
} 
rasisme sehingga terkadang mengusik apa yang disebut dengan istilah SARA (Suku, Agama, Ras dan Antar golongan)". 3

Dewasa ini, toleransi antar umat beragama sangat kita butuhkan untuk menghindari perpecahan yang mungkin akan terjadi di kalangan masyarakat itu sendiri. Kita mengingat kembali akan kasus bom bunuh diri yang terjadi pada pasangan suami istri di depan pintu gerbang Gereja Katedral di jalan Kajaolalido, M.H Thamrin, Kota Makassar, Provinsi Sulawesi Selatan, Ahad pagi pada tanggal 28 Maret 2021 yang mengakibatkan 20 orang petugas keamanan dan jemaah gereja lukaluka. Dikutip dari wawancara Tempo.co (Rahma, 2021) bersama dengan Kepala Kepolisian RI Jenderal Listyo Sigit Prabowo mengatakan bahwa "Atas inisial W, pelaku otak perakit bom sudah kami amankan". Wawancara tersebut berlangsung di kantornya, Jakarta Selatan, pada Rabu malam, 31 Maret 2021. Pelaku tersebut terduga sebagai teroris yang menjadi perakit bom bunuh diri di Gereja Katedral Makassar, Sulawesi Selatan. ${ }^{4}$

Kasus tersebut menandakan bahwa isu Radikalisme sudah sangat dekat dengan kita. Gerakan Radikalisme khususnya Radikalisme yang mengatasnamakan agama telah menjadi ancaman tidak hanya bagi multikultural tetapi juga bagi Negara Kesatuan Republik Indonesia (NKRI). Ironisnya mahasiswa menjadi salah satu sasaran utama perkembangan radikalisme di kampus. Oleh karena itu, sebagai mahasiswa yang terpelajar sudah seharusnya kita meningkatkan toleransi beragama antar sesama dalam upaya mencegah timbulnya potensi serta isu Radikalisme dikalangan mahasiswa.

Dalam kasus-kasus serupa, banyaknya mahasiswa yang terlibat tidak terlepas dari faktor internal dan eksternal pada mahasiswa itu sendiri. Usia mahasiswa yang sedang bertransisi menjadi dewasa muda, dimana usia tersebut merupakan tahap yang krusial dalam mencari jati diri dan seringnya muncul berbagai rasa ingin tahu lebih yang ditandai dengan krisis identitas. Faktor internal yang dimaksud oleh peneliti disini adalah mahasiswa yang memiliki pengetahuan rendah mengenai agama cenderung akan lebih rawan dipengaruhi dan dimasuki berbagai ideologi radikal, sedangkan mahasiswa yang memiliki pengetahuan yang lebih luas mengenai agama akan bersifat lebih terbuka dan lebih mudah menerima berbagai perbedaan dan

\footnotetext{
${ }^{3}$ Kahmad (2009), Sosiologi Agama. Bandung: PT. Remaja Rosdakarya

${ }^{4}$, Website Tempo.Co, Densus 88 Tangkap Otak Perakit Bom Bunuh Diri Gereja Katedral Makassar, Tempo.Co: 2021. Akses; Sabtu, 23 Oktober 2021, https://nasional.tempo.co
} 
keanekaragaman dalam menjalani kehidupan kampus. Selanjutnya, yaitu faktor eksternal yang dimaksud disini adalah kondisi kultural kampus yang terbuka dan mudah dimasuki berbagai ideologi, termasuk ideologi radikal. Hal ini disebabkan, kampus dengan segala kegiatannya cenderung sulit untuk bisa dikontrol mengingat dunia kampus memberikan kebebasan bagi setiap organisasi ekstra maupun intra untuk berekspresi serta melakukan berbagai kegiatan dikampus. Hal tersebut tanpa disadari tentunya telah memberi peluang bagi gerakan penanam radikal untuk mencuci otak mahasiswa. Hal tersebut biasanya dilakukan dengan sembunyisembunyi atau tertutup dengan mengatasnamakan agama yang dibungkus dalam bentuk dakwah pada umumnya. Sebagaimana yang dikemukakan (Azra, Menuju Masyarakat Madani: Gagasan, Fakta dan Tantangan, 1999) bahwa "Penguatan pemahaman keagamaan mahasiswa khususnya pada sikap keragaman agama, toleransi intraagama dan antar agama serta antar umat beragama dan Negara sangat penting dilakukan untuk mengantisipasi gerakan Radikalisme dalam dunia kampus". 5 (Irham, 2015) dalam penelitian juga menyatakan bahwa "Jika pemahaman keagamaan sempit dan ekslusif tidak menutup kemungkinan akan cenderung lebih tertutup dan tidak menerima keberagaman". 6

Berangkat dari pemaparan diatas, peneliti merasa tertarik untuk melakukan suatu penelitian sederhana tentang tingkat toleransi beragama mahasiswa terhadap isu radikalisme. Mengingat bahwasannya kampus dan mahasiswa pada saat ini telah menjadi salah satu sasaran empuk dari tindakan makar Radikalisme, tak terkecuali dengan kampus yang menjadi kiblat bagi pelajar di sulawesi bagian Indonesia Tengah yaitu Universitas Hasanuddin. Dengan demikian, peneliti akan mencoba untuk mensurvei pengaruh tingkat toleransi beragama terhadap isu Radikalisme Mahasiswa FISIP Universitas Hasanuddin. Penelitian ini berjudul "Pengaruh Tingkat Toleransi Beragama Terhadap Isu Radikalisme Mahasiswa Fisip Universitas Hasanuddin”.

\section{B. TINJAUAN TEORITIS}

\section{Pengertian Toleransi Beragama}

Toleransi adalah istilah dalam suatu konteks yang biasanya berhubungan dengan sosial, budaya dan agama yang artinya sikap yang menghargai dan

\footnotetext{
${ }^{5}$ Azra (2017), Menuju Masyarakat Madani: Gagasan, Fakta dan Tantangan. Bandung: PT. Remaja Rosda Karya Bandung

${ }^{6}$ Irham (2015:95), Pesantren dan Perkembangan Politik Pendidikan Agama di Indonesia, Volume 13, Nomor 01
} 
memahami kelompok yang berbeda-beda dalam suatu masyarakat. Salah satunya yaitu toleransi dalam beragama yang dimana penganut mayoritas dalam suatu agama masyarakat menerima adanya keberadaan agama-agama lainnya atau sikap seseorang yang saling menghormati setiap tindakan yang dilakukan orang lain. (Berty, 2021)

Toleransi dalam pergaulan hidup antara umat beragama didasarkan kepada tiap agama menjadi tanggung jawab pemeluk agama itu sendiri dan mempunyai bentuk ibadat atau ritual dengan sistem dan cara tersendiri yang dibebankan dan menjadi tanggung jawab bagi pemeluk agamanya, atas dasar itu maka toleransi dalam pergaulan hidup antar umat beragama bukanlah toleransi dalam masalahmasalah keagamaan melainkan perwujudan sikap keberagaman pemeluk suatu agama dalam pergaulan hidup antara orang yang tidak seagama dalam masalahmasalah kemasyarakatan atau kemaslahatan umum. (Naim, 1983)

Kita dapat melihat beberapa perspektif tersebut, pada dasarnya toleransi dalam beragama disini adalah kita harus memiliki sikap saling menghargai antar sesama umat beragama agar dalam menjalani kehidupan sehari-hari kita bisa terhidar dari isu radikalisme yang mengatasnamakan agama yang dapat memecah belah persatuan. Selain itu pengertian dari toleransi beragama juga dikemukakan oleh (Djauhar, 1983) bahwa, pengakuan adanya kebebasan setiap warga Negara untuk memeluk suatu agama yang menjadi keyakinannya dan kebebasan untuk menjalankan ibadahnya.

2. Pengertian Radikalisme

Dalam perkembangannya, radikalisme dapat diartikan sebagai sebuah perubahan atau pembaharuan sosial dan politik secara drastis dengan menggunakan cara-cara kekerasan yang dilakukan oleh paham atau aliran tertentu dengan mengatasnamakan agama.

Menurut (Wilner., 2009) mengatakan bahwa "proses yang terjadi dalam radikalisme adalah radikalisasi, yang di definisikan sebagai proses personal di mana individu mengadopsi idealisme dan aspirasi politik, sosial atau agama secara ekstrem, dimana dalam pencapaian tujuannya membenarkan penggunaan kekerasan tanpa pandang bulu, sehingga mempersiapkan dan memotivasi seseorang untuk mencapai perilaku kekerasan.” Agama merupakan lahan empuk untuk menjadi crying banner dalam melakukan tindakan anarkis, yang juga samasama didasari pada pembacaan dan konstruksi tekstualitas yang ada dalam agama 
itu sendiri. ${ }^{7}$ Menurut (Crawford, 2001), Dalam relasinya dengan politik, agama dengan mudah terseret dalam kancah radikalisme dengan di politisasinya agama sebagai sumber radikalisme terbuka, yang sebenarnya lebih didasari oleh melemahnya sistem dan institusi politik yang ada. ${ }^{8}$

Berdasarkan beberapa pendapat tersebut dapat dipahami bahwa Radikalisme dalam pandangan agama dapat diartikan sebagai paham keagamaan yang mengacu kepada pondasi agama dengan fanatisme keagamaan yang sangat tinggi, sehingga dalam penerapannya tidak jarang penganut paham/aliran tersebut cenderung menggunakan kekerasan untuk mengaktualisasikan paham keagamaan yang dianut dan di yakininya.

\section{METODE PENELITIAN}

Jenis penelitian ini adalah penelitian survei dengan menggunakan metode penelitian kuantitatif. Penulis menggunakan jenis penelitian survei karena dalam pengumpulan data, angket/kuesioner yang telah di isi dari para responden digunakan sebagai metode pokok dalam menyelesaikan penelitian. Sebagaimana yang dikemukakan oleh (Masri Singarimbun, 1989), bahwa "penelitian survei adalah penelitian yang mengambil sampel dari satu populasi dan menggunakan kuesioner sebagai alat pengumpulan data yang pokok." Sedangkan penelitian kuantitatif digunakan karena penelitian kuantitatif bertujuan untuk mengetahui hubungan dua variabel atau lebih yang bersifat sebab akibat (Kausal), menguji teori, dan analisa data dengan menggunakan statistik untuk menguji hipotesis. (Sugiyono, 2013, p. 23)

Lokasi dalam penelitian ini adalah Fakultas Ilmu Sosial dan Ilmu Politik (FISIP) Universitas Hasanuddin. FISIP terletak di dalam kampus utama Universitas Hasanuddin di Jl.Perintis Kemerdekaan No.KM.10, Tamalanrea Indah, Kec. Tamalanrea, Kota Makassar, Sulawesi Selatan.

Berdasarkan kutipan sebelumnya, maka penggunaan pendekatan dalam penelitian ini adalah pendekatan kuantitatif dengan menggunakan jenis penelitian survei. Pendekatan tersebut dilakukan karena dilihat dari sisi dan kegunaannya sesuai dengan penelitian yang penulis lakukan untuk menguji seberapa tinggi atau rendahnya pengaruh antara variabel independent, yaitu tingkat toleransi beragama mahasiswa

\footnotetext{
${ }^{7}$ Azyumardi Azra, Menuju Masyarakat Madani: Gagasan, Fakta dan Tantangan, 1999.

8 Beverly Crawford, "Politik Identitas: Sebuah Pendekatan Kelembagaan", dalam Jurnal Gerbang, Nomor 10,Vol. IV, Juni-Agustus 2001
} 
dengan variabel dependen pengaruh tingkat toleransi beragama terhadap isu radikalisme di kalangan Mahasiswa. Berdasarkan hasil angket/kuesioner yang telah penulis sebarkan kepada responden penelitian.

Populasi dalam penelitian ini adalah seluruh mahasiswa FISIP Universitas Hasanuddin. Penentuan populasi dalam penelitian sangat penting untuk dilakukan karena populasi akan memberikan batasan terhadap objek yang akan diteliti, seperti yang dikemukakan oleh (Sugiyono, 2013) bahwa, "Populasi adalah wilayah generalisasi yang terdiri atas obyek/subyek yang mempunyai kuantitas dan karakteristik tertentu yang ditetapkan oleh peneliti untuk dipelajari dan kemudian ditarik kesimpulannya".

Sampel pada penelitian ini adalah mahasiswa FISIP Universitas Hasanuddin sebanyak 30 orang. Sampel dalam penelitian ini ditentukan dengan menggunakan teknik simple Random Sampling, yaitu suatu cara dalam pengambilan sampel dengan cara acak tanpa memperhatikan strata yang ada dalam populasi. (Sugiyono, 2013, p. 82)

Pengumpulan data dalam penelitian ini menggunakan kuesioner semi tertutup. Dimana yang dimaksud dengan angket atau kuesioner tertutup menurut (Nasution, 2003) adalah "Angket tertutup terdiri atas pertanyaan atau pernyataan dengan sejumlah jawaban tertentu sebagai pilihan”.

Dalam penelitian kuantitatif, analisis data merupakan kegiatan setelah data dari seluruh responden atau sumber data lain terkumpul. (Sugiyono, 2013, p. 147). Teknik pengolahan dan analisis data kuantitatif yang digunakan dalam penelitian ini adalah teknik statistik deskriptif. (Sugiyono, 2013, pp. 207-208) mengemukakan bahwa: "statistik deskriptif adalah teknik statistik yang digunakan untuk menganalisis data dengan cara mendeskripsikan atau menggambarkan data yang telah terkumpul sebagaimana adanya tanpa bermaksud membuat kesimpulan yang berlaku untuk umum atau generalisasi. Statistik deskriptif dapat digunakan bila peneliti hanya ingin mendeskripsikan data sampel dan tidak ingin membuat kesimpulan yang berlaku untuk populasi dimana sampel diambil.” Karena dalam penelitian ini hanya menggunakan sampel sebanyak 30 dan tidak mencapai setangah dari populasi maka kesimpulan akhir dalam penelitian ini tidak bisa di generalisasikan untuk umum.

Penulis melakukan pengolahan data kuesioner dengan bantuan software statistik SPSS ver.28.0 yang kemudian di olah secara manual untuk mendapatkan data penelitian yang diinginkan. Setelah melakukan pengolahan statistik, kemudian penulis 
menggunakan teknik analisis data yang dikemukakan oleh Miles dan Huberman (Sugiyono, 2013, p. 246) "Yang mencakup reduksi data (data reduction), penyajian data (data display), dan kesimpulan atau verifikasi conclusion drawing).

1. Reduksi Data (Data Reduction)

Reduksi data dilakukan untuk mempermudah pengolahan data mentah yang telah di dapatkan oleh penulis dilapangan. Sehingga dalam pengolahan data, penulis lebih mudah untuk memahami data yang telah terkumpul. Adapun dalam penelitian ini penulis mengumpulkan data kuesioner yang telah disebar kepada sampel yang berada dilingkup FISIP Universitas Hasanuddin serta mengetahui beberapa perspektif Mahasiswa tentang toleransi beragama dan pengaruhnya terhadap isu radikalisme.

2. Penyajian Data (Data Display)

Selanjutnya yaitu penyajian data yang telah diolah dalam bentuk matriks, tabel, diagram dan bentuk representasi visual lainnya yang sesuai dengan keadaan data lapangan. Display data dalam penelitian ini merupakan hasil pengolahan data dengan menggunakan bantuan software SPSS ver.28.0. yang juga digunakan untuk mengukur validitas, reliabilitas, dan korelasi dari variabel penelitian.

3. Kesimpulan (Verivication)

Kesimpulan diperoleh dari hasil penelitian dengan mengacu pada rumusan masalah yang telah diuraikan terlebih dahulu. Kesimpulan dalam penelitian ini akan di sajikan dalam bentuk yang mudah untuk dipahami dalam menyimpulkan pengaruh tingkat toleransi beragama terhadap isu radikalisme Mahasiswa FISIP Universitas Hasanuddin.

\section{PEMBAHASAN DAN HASIL PENELITIAN}

1. Tingkat Toleransi Beragama Mahasiswa

Deskripsi data penelitian yang akan dijelaskan telah di olah dan di analisis terlebih dahulu oleh penulis menggunakan bantuan software SPSS ver.28.0 dan untuk pengolahan reduksi kata yang dikumpulkan dari para responden penulis di bantu dengan menggunakan software Microsoft Excel. Berikut merupakan hasil analisis skor data responden penelitian mengenai tingkat toleransi beragama mahasiswa FISIP Universitas Hasanuddin. 


\begin{tabular}{|c|c|c|c|}
\hline No & Tingkat Toleransi Beragama Mahasiswa & Frekuensi & Persentase (\%) \\
\hline 1 & Tinggi (40-44) & 19 & 63,3 \\
\hline 2 & Sedang (36-39) & 7 & 23,3 \\
\hline 3 & Rendah (32-35) & 4 & 13,3 \\
\hline \multicolumn{2}{|c|}{} & 30 & $100 \%$ \\
\hline
\end{tabular}

Sumber: hasil pengolahan data melalui SPSS ver.28.0

Pada tabel tersebut, diketahui bahwa tingkat pengetahuan agama mahasiswa FISIP UNHAS berada pada kategori tinggi yaitu sebanyak 63,3\%. Selanjutnya tingkat pengetahuan agama mahasiswa yang dikategorikan sedang berada pada interval kedua yaitu, 23,3\%, sedangkan tingkat pengetahuan agama mahasiswa yang berada pada kategori rendah hanya memiliki persentase sebesar 13,3\%. Ini menandakan bahwa tingkat pengetahuan agama mahasiswa yang telah di uji coba kepada 30 sampel tersebut masuk kedalam kategori tinggi. Yang dimana hal tesebut mengindikasikan bahwa tingkat pengetahuan agama mahasiswa dalam uji coba tersebut sudah optimal. Untuk lebih jelasnya dapat dilihat pada grafik berikut:

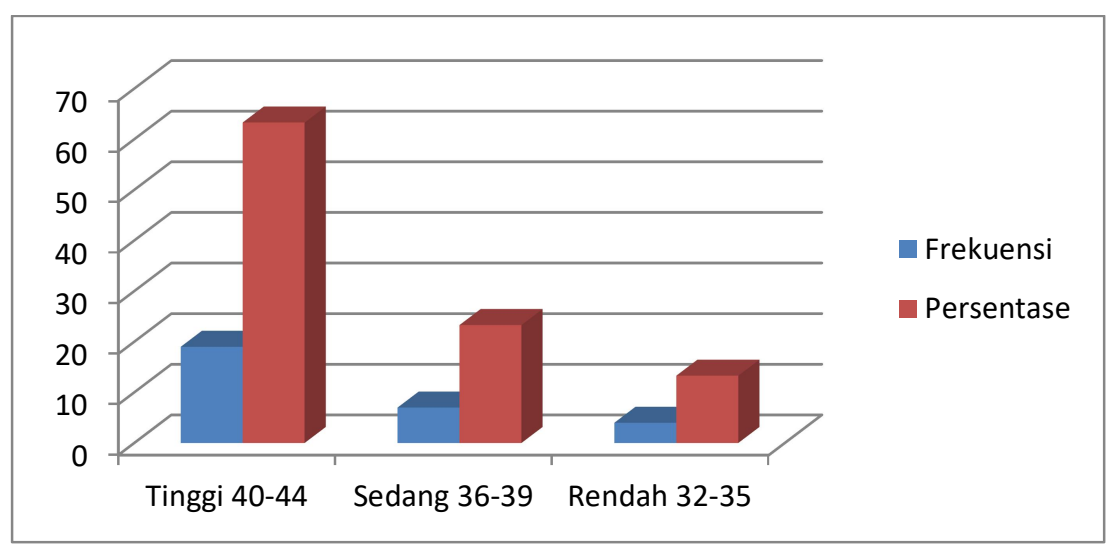

Gambar 1. Klasifikasi tingkat toleransi beragama

2. Pengaruh Antara Tingkat Toleransi Beragama Terhadap Isu Radikalisme

Selanjutnya akan di paparkan deskripsi data penelitian mengenai pengaruh antara tingkat toleransi beragama yang telah kita bahas diatas, terhadap isu radikalisme dikalangan mahasiswa FISIP UNHAS. 


\begin{tabular}{|c|c|c|c|}
\hline No & Isu Radikalisme & Frekuensi & Persentase (\%) \\
\hline 1 & Sangat Tidak Setuju & 11 & 36,7 \\
\hline 2 & Tidak Setuju & 8 & 26,7 \\
\hline 3 & Setuju & 7 & 23,3 \\
\hline 4 & Sangat Setuju & 4 & 13,3 \\
\hline & Jumlah & 30 & $100 \%$ \\
\hline
\end{tabular}

Sumber: hasil pengolahan data melalui SPSS ver.28.0

Pada tabel tesebut, diketahui bahwa isu radikalisme di kalangan mahasiswa menunjukkan sikap yang sangat tidak setuju yaitu sebesar $36,7 \%$, dan tidak setuju sebesar $26,7 \%$. Tapi masih cukup banyak mahasiswa yang setuju dengan adanya isu radikalisme yaitu sebesar $23,3 \%$ dan sangat setuju mendapatkan persentase sebesar $13,3 \%$. Untuk lebih jelasnya dapat dilihat pada grafik berikut:

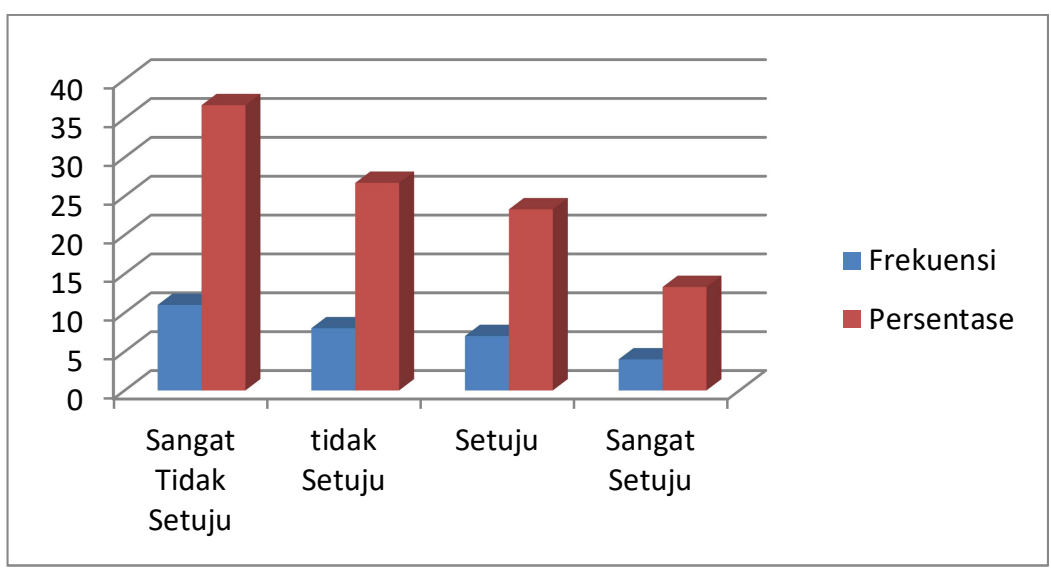

Gambar 2. klasifikasi pengaruh terhadap isu radikalisme

Data yang diperoleh pada tabel tersebut menunjukkan bahwa dari 30 responden penelitian, masih ada beberapa mahasiswa yang menyatakan setuju dengan isu radikalisme. Walaupun demikian pada umumnya mahasiswa yang menjadi sampel uji coba penelitian tersebut tetap menyatakan tidak setuju pada gerakan isu radikalisme. Bahkan sebanyak 36,7\% mahasiswa menentang keras atau sangat tidak setuju pada penyebaran isu radikalisme yang mengatasnamakan agama. Hal tersebut mengindikasikan bahwa tingginya rasa toleransi beragama yang ditunjukkan oleh kalangan mahasiswa FISIP UNHAS berada pada level tinggi yang dimana hal tersebut membuat penyebaran isu radikalisme tidak terlalu berpengaruh dikalangan mahasiswa.

Temuan penulis ini sejalan dengan pendapat (Rokhmad, 2012) yang menyatakan bahwa: "Salah satu faktor yang mempengaruhi persepsi siswa terhadap 
gerakan radikalisme berbasis agama adalah tingkat pengetahuan agama.” Berdasarkan pendapat Abu Rokhmad tersebut pengetahuan agama yang dimilki seseorang akan menjadi landasan bagi seorang muslim maupun non-muslim untuk menolak gerakan radikalisme dalam agama.

\section{E. KESIMPULAN}

Berdasarkan hasil penelitian tentang pengaruh tingkat toleransi beragama terhadap isu radikalisme mahasiswa FISIP Universitas Hasanuddin yang telah dilakukan oleh penulis, maka dapat ditarik kesimpulan sebagai berikut:

1. Mahasiswa FISIP Universitas Hasanuddin memiliki tingkat toleransi beragama yang tinggi. Berdasarkan hasil olah data yang dilakukan kepada sampel sebanyak 30 menunjukkan tingkat pengetahuan agama mahasiswa FISIP UNHAS berada pada kategori tinggi yaitu sebanyak 63,3\%. Selanjutnya tingkat pengetahuan agama mahasiswa yang dikategorikan sedang berada pada interval kedua yaitu, $23,3 \%$, sedangkan tingkat pengetahuan agama mahasiswa yang berada pada kategori rendah hanya memiliki persentase sebesar 13,3\%. Yang dimana hal tesebut mengindikasikan bahwa tingkat pengetahuan agama mahasiswa dalam uji coba tersebut sudah optimal.

2. Tingkat toleransi beragama yang tinggi dikalangan mahasiswa tersebut memberikan pengaruh yang positif terhadap rendahnya isu radikalisme. Dari hasil olah data yang telah dilakukan oleh penulis menunjukkan isu radikalisme di kalangan mahasiswa menunjukkan sikap yang sangat tidak setuju yaitu sebesar $36,7 \%$, dan tidak setuju sebesar $26,7 \%$. Tapi masih cukup banyak mahasiswa yang setuju dengan adanya isu radikalisme yaitu sebesar $23,3 \%$ dan sangat setuju mendapatkan persentase sebesar 13,3\%. Hal tersebut mengindikasikan bahwa penyebaran isu radikalisme tidak terlalu berpengaruh dikalangan mahasiswa FISIP Universitas Hasanuddin. 


\section{DAFTAR PUSTAKA}

Azra, A. (1999). Menuju Masyarakat Madani: Gagasan, Fakta dan Tantangan. Bandung: PT. Remaja Rosda Karya Bandung.

Berty, R. (2021). Penanaman Nilai-nilai Toleransi Antar Umat Beragama. Surakarta: Repository IAIN Surakarta.

Crawford, B. (2001). Politik Identitas: Sebuah Pendekatan Kelembagaan. Jurnal Gerbang.

Djauhar, Z. (1983). Hasil Musyawarah antar Umat Beragama. 120.

Hardjana. (1993). Penghayatan Agama yang Otentik dan Tidak Otentik. 115.

Irham. (2015). Pesantren dan Perkembangan Politik Pendidikan Agama di Indonesia. Pendidikan Agama Islam Ta'lim Universitas Pendidikan Indonesia, 13.

Kahmad, D. (2009). Sosiologi Agama. Bandung: PT. Remaja Rosdakarya.

Kusumohamidjojo, B. (2000). Kebhinekaan Masyarakat Indonesia: Suatu Problematik Filsafat Kebudayaan. Jakarta: Grasindo.

Masri Singarimbun, S. E. (1989). Metode Penelitian Survei. Jakarta: LP3ES.

Moh.Yamin, V. A. (2011). Meretas Pendidikan Toleransi. Madani Media, 28.

Naim, S. (1983). Kerukunan Antar Umat Beragama. 60.

Nasikun. (2007). Sistem Sosial Indonesia. Jakarta: PT. Raja Grafindo Persada.

Nasution. (2003). Metode Research: Penelitian Ilmiah. Jakarta: Bumi Aksara.

Rahma, A. (2021, April Kamis). Densus 88 Tangkap Otak Perakit Bom Bunuh Diri Gereja Katedral Makassar. Retrieved Oktober 6, 2021, from Tempo.co: https://nasional.tempo.co/read/1448123/densus-88-tangkap-otak-perakit-bom-bunuhdiri-gereja-katedral-makassar

Rokhmad, A. (2012). Radikalisme Islam dan Upaya Deradikalisasi Paham Radikal. Jurnal Walisongo Universitas Diponegoro Semarang, 81.

Sugiyono. (2013). Metode Penelitian Pendekatan Kuantitatif, Kualitatif, dan R\&D. Bandung: Alfabeta.

Wilner., A. P.-J. (2009). Homegrown Terrorism and Transformative Learning. Canadian Political Science Association Conference, (p. 8). Ottawa. 